\title{
BEYOND THE 'BALANCE OF NATURE': PASTORALISTS' ALTERNATIVE PERSPECTIVES ON SUSTAINABILITY
}

\section{Ian Scoones}

PASTRES programme, Institute of Development Studies, University of Sussex Email: i.scoones@ids.ac.uk

David Attenborough's mission to restore the balance of nature in the documentary, A Life on Our Planet: My Witness Statement, is at once inspiring and concerning. What if the balance of nature doesn't exist? What if this mission is misplaced?

The film is full of the familiar tropes of nature documentaries, once again repeated with Attenborough's familiar gravitas. Human beings have overrun the world. Wilderness has been destroyed. Stability and balance - the 'security and stability of the Holocene' - have been upset. Our singular world - invoking the iconic picture of 'only one earth' (Ward and Dubos 1972) seen from space - becomes threatened. Catastrophe and crisis are the impending result. Unless of course 'we' (a rather generic humanity) can restore stability through protecting biodiversity; in his words, 'rewilding the world'.

Those of us brought up on Attenborough's amazing natural history programmes have got used to the standard storyline, centred on a Malthusian narrative. Too many humans can damage the awe-inspiring, pristine nature depicted in the films. Yet, unlike most of his previous documentaries, this one goes a step further. An hour of the now-familiar narrative culminates in some tragic yet bizarre imagery of dying walruses in front of an appalled Davos audience. And then the argument shifts.

In this very personal testimony, a 93-year-old Attenborough argues how we have to rediscover how to be sustainable: moving from being 'apart from nature to being part of nature'; 'working with nature rather than against it'. In guarded tones for sure, a more critical perspective is offered: one that identifies capitalism - without naming it here, although he does so in a BBC interview ${ }^{1}$ - and the structural relations of politics and economy as the driving forces behind the destruction of the non-human world.

The inevitability of the countdown to doomsday can be challenged, he argues, even if ultimately by some odd techno-utopian solutions such as remote-controlled drones harvesting forests. Nature will and must endure, he proclaims: stability will be restored, with or without humans. 


\section{Lessons from non-equilibrium drylands}

It is with this focus on stability and balance, the restoration of the wild and the assumptions of equilibrium that I depart from Attenborough's analysis.

Lessons from dryland pastoral areas have long shown that such systems are mostly not at equilibrium (Behnke et al. 1993). The balance of nature does not exist: disruption, variability and instability are the norm. And, as a result, the ideas of restoration, carrying capacity and set, naturalised limits do not apply. Vegetation frequently does not change in relation to animal populations in patterns of simple, predictable Clementsian succession, as suggested by the images of the return of nature to the Chernobyl site in Ukraine. Shocks and stresses will always disrupt. And pastoralists living from non-equilibrium rangelands must adapt, frequently through flexible movement assisted by skilled herding and livestock management (Krätli 2019).

Because natural systems are very often not at equilibrium, then we cannot predict what will happen in the future with certainty (Scoones 1999). The refrain in the film that science predicts what will happen in ten, twenty, thirty, a hundred years may not turn out to be the case. Uncertainty, even ignorance, dominates. While this is no argument for denying the very real challenges of climate change and biodiversity loss highlighted by the film, we know much less about the future than is frequently claimed, making embracing and navigating uncertainty vital (Scoones 2019). Films made thirty years ago about pastoralism frequently predicted its demise, but resilience through adaptation and transformation is a key feature of human innovation and ingenuity.

Pastoralists are innovators par excellence. It may be that the traditional transhumant movements no longer exist, but pastoralists may use other means to live with and from uncertainty (Krätli and Schareika 2010): using trucks to move animals or fodder, developing key resource areas through cultivation to offset drought impacts, switching species and their composition, adding other livelihood activities to the mix. The search for reliability involves reinventing the infrastructure of daily existence in a highly uncertain world (Roe 2020). This may mean rather more mundane, practical solutions to seeking reliability and sustainability in the face of uncertain challenges than high-tech drones or lab-grown meat.

\section{Constructed limits, collective responses}

As Giorgos Kallis (2019) argues forcefully, limits are constructed; they are collective choices. Nature is abundant and generous and can offer many opportunities if we allow human agency and democracy to thrive. In other words, 
the (falsely interpreted, he argues) Malthusian tropes of nature documentaries may be misplaced. Negotiating our way in the Anthropocene - where human intervention in the natural world dominates, as Attenborough so vividly shows - requires learning, adaptation and innovation to achieve solutions, but ones that are local, embedded and suited to different settings. Collective choices about setting limits are about generating an alternative worldview that in turn challenges the rapaciousness of capitalism.

Pastoralists have proved brilliant at addressing the challenges of dryland areas over millennia. Yet they are often cast as the enemy of sustainability, causing environmental destruction and following 'backward' lifestyles. Diagnoses of environmental challenges too often fail to understand the specificities of human-non-human relations in dryland areas. The solution is not to abandon meat and milk production where alternatives are impossible; rewild the rangelands with trees that will inevitably die; or seek high-tech alternatives to already-sustainable production systems, as the generic responses to climate change often suggest. Instead, by accepting instability, variability and nonequilibrium dynamics and seeking out autonomously-defined limits, based on local knowledge and an embedded ethics of care, alternatives can instead emerge based on how pastoralists see, manage and value the world.

We may all live on only one earth, but there are many different people living in many different environments. The uniform globalism of nature documentaries and many (Northern) climate campaigners can undermine a more variegated approach, which will be needed to address these very real challenges. By allowing a flourishing of ideas and practices that work with nature, such as those offered by pastoralists, the challenges of an uncertain, turbulent world can be addressed, but in a rather different way from that envisaged by Sir David.

\section{Acknowledgements}

This work has been supported by a European Research Council Advanced Grant to the PASTRES (Pastoralism, Uncertainty, Resilience) programme (pastres.org)

\section{References}

Behnke, R., I. Scoones and C. Kerven (eds). 1993. Range Ecology at Disequilibrium: New Models of Natural Variability and Pastoral Adaptation in African Savannas. London: Overseas Development Institute.

Kallis, G., 2019. Limits: Why Malthus was wrong and Why Environmentalists Should Care. Stanford University Press. https://doi.org/10.1515/9781503611566 


\section{A Life on Our Planet: Beyond the 'Balance of Nature'}

Krätli, S., 2019. Pastoral Development Orientation Framework: Focus on Ethiopia. Aachen: Misereor.

Krätli, S. and N. Schareika. 2010. 'Living off uncertainty: the intelligent animal production of dryland pastoralists'. The European Journal of Development Research 22 (5): 605-622.

https://doi.org/10.1057/ejdr.2010.41

Roe, E. 2020. 'A new policy narrative for pastoralism? Pastoralists as reliability professionals and pastoralist systems as infrastructure'. STEPS Working Paper 113. Brighton: STEPS Centre.

https://opendocs.ids.ac.uk/opendocs/handle/20.500.12413/14978

Scoones, I. 2019. 'What is uncertainty and why does it matter?' STEPS Working Paper 105. Brighton: STEPS Centre.

https://opendocs.ids.ac.uk/opendocs/handle/20.500.12413/14470

Scoones, I. 1999. 'New ecology and the social sciences: what prospects for a fruitful engagement?' Annual Review of Anthropology 28 (1): 479-507.

https://doi.org/10.1146/annurev.anthro.28.1.479

Ward, B. and R. Dubos. 1972. Only One Earth. The Care and Maintenance of a Small Planet. Harmondsworth: London: Penguin Books. 